\title{
Serotonin 6 receptor controls alzheimer's disease and depression
}

\author{
Hyung-Mun Yun ${ }^{1, *}$, Kyung-Ran Park ${ }^{2, *}$, Eun-Cheol Kim ${ }^{1}$, Sanghyeon Kim ${ }^{4}$ and Jin \\ Tae Hong ${ }^{3}$ \\ ${ }^{1}$ Department of Maxillofacial Tissue Regeneration, School of Dentistry and Research Center for Tooth and Periodontal \\ Regeneration (MRC), Kyung Hee University, Seoul, Republic of Korea \\ 2 Department of Oral \& Maxillofacial Regeneration, Kyung Hee University, Seoul, Republic of Korea \\ ${ }^{3}$ College of Pharmacy and Medical Research Center, Chungbuk National University, Chungbuk, Republic of Korea \\ ${ }^{4}$ Stanley Brain Research Laboratory, Stanley Medical Research Institute, Rockville, MD, USA \\ * These authors have contributed equally to this work \\ Correspondence to: Jin Tae Hong, email: jinthong@chungbuk.ac.kr
}

Sanghyeon Kim, email: Kims@stanleyresearch.org

Keywords: 5-HT $\mathrm{R}$, serotonin, APBA1/2, alzheimer's disease, depression

Received: August 19, $2015 \quad$ Accepted: August 29, $2015 \quad$ Published: September 22, 2015

This is an open-access article distributed under the terms of the Creative Commons Attribution License, which permits unrestricted use, distribution, and reproduction in any medium, provided the original author and source are credited.

\section{ABSTRACT}

Alzheimer's disease (AD) and depression in late life are one of the most severe health problems in the world disorders. Serotonin 6 receptor $\left(5-\mathrm{HT}_{6} \mathrm{R}\right)$ has caused much interest for potential roles in AD and depression. However, a causative role of perturbed $5-\mathrm{HT}_{6} \mathrm{R}$ function between two diseases was poorly defined. In the present study, we found that a 5-HT ${ }_{6} \mathrm{R}$ antagonist, SB271036 rescued memory impairment by attenuating the generation of $A \beta$ via the inhibition of $y$-secretase activity and the inactivation of astrocytes and microglia in the AD mouse model. It was found that the reduction of serotonin level was significantly recovered by SB271036, which was mediated by an indirect regulation of serotonergic neurons via GABA. Selective serotonin reuptake inhibitor (SSRI), fluoxetine significantly improved cognitive impairment and behavioral changes. In human brain of depression patients, we then identified the potential genes, amyloid beta (A4) precursor protein-binding, family A, member 2 (APBA2), well known AD modulators by integrating datasets from neuropathology, microarray, and RNA seq. studies with correlation analysis tools. And also, it was demonstrated in mouse models and patients of AD. These data indicate functional network of $5-\mathrm{HT}_{6} \mathrm{R}$ between $\mathrm{AD}$ and depression.

\section{INTRODUCTION}

Alzheimer's disease (AD) and depression are disorders of enormous and increasing public health significance [1]. Considerably higher incidences of depression are caused among aging [2]. Depression may be the initial sign of neurodegenerative disease and thus may be regarded as a risk factor for later development of $\mathrm{AD}$ [3]. Some studies showed higher rates of AD in those who have suffered from depression $[1,4]$, suggesting that the neurodegenerative process is accelerated [5-6]. Thus, depression is a potential risk factor for AD. However, the relationship between $\mathrm{AD}$ and depression is incompletely understood and probably complex.

Serotonin 6 receptor $\left(5-\mathrm{HT}_{6} \mathrm{R}\right)$ is one of the latest cloned receptors among the known 5-HT receptors and positively coupled to adenylate cyclase via Gs proteins [7]. The receptor has been reported to be intensively expressed in the central nervous system (CNS), especially in the striatum, hippocampus, and cortex [8]. 5- $\mathrm{HT}_{6} \mathrm{R}$ has shown a high affinity for antipsychotic drugs (loxapine and clozapine) as well as tricyclic antidepressant drugs (amitryptyline, clomipramine, and amoxipine) [9]. The abundant distribution in limbic region that participates in the control of mood and emotion, and the high affinity for antipsychotic and antidepressant compounds have 
caused much interest for the significant roles in the CNS [10-11]. In AD, considerable reductions in 5- $\mathrm{HT}_{6} \mathrm{R}$ density have been found in cortical areas of AD patients [12]. In preclinical studies of rodents and primates, it was reported that $5-\mathrm{HT}_{6} \mathrm{R}$ antagonists enhance cognitive performance in a wide variety of learning and memory paradigms and also results in antidepressant-like activity [13-14]. In depression, preclinical data suggest potential roles for 5-HT 6 R. 5- $\mathrm{HT}_{6} \mathrm{R}$ antagonists have also been reported to produce antidepressant-like effects using the forced swim and tail suspension tests in both rats and mice [15-16]. Nevertheless, causative studies for functional network of 5-HT ${ }_{6} \mathrm{R}$ between AD and depression were not defined. We, therefore, hypothesized that $5-\mathrm{HT}_{6} \mathrm{R}$ could play a critical role in link between $\mathrm{AD}$ and depression, which could unveil the correlation between $\mathrm{AD}$ and depression via common network of $5-\mathrm{HT}_{6} \mathrm{R}$.

In present study, we demonstrated that $5-\mathrm{HT}_{6} \mathrm{R}$ regulates memory impairment and serotonin, which is reduced by GABA in the $\mathrm{AD}$ mouse model. We found that APBA1/2 related with amyloid beta A4 precursor protein (APP) metabolism in AD [17-19] was correlated with $5-\mathrm{HT}_{6} \mathrm{R}$ in depression patients, and regulated by $5-\mathrm{HT}_{6} \mathrm{R}$ in the AD mouse model, suggesting significant implications for the network of $5-\mathrm{HT}_{6} \mathrm{R}$ between $\mathrm{AD}$ and depression.

\section{RESULTS}

\section{5-HT ${ }_{6} \mathrm{R}$ modulates cognitive impairment, amyloidogenesis, and neuroinflammation in the AD mouse model}

In order to identify whether a $5-\mathrm{HT}_{6} \mathrm{R}$ antagonist, SB271046 could affect memory dysfunction in the
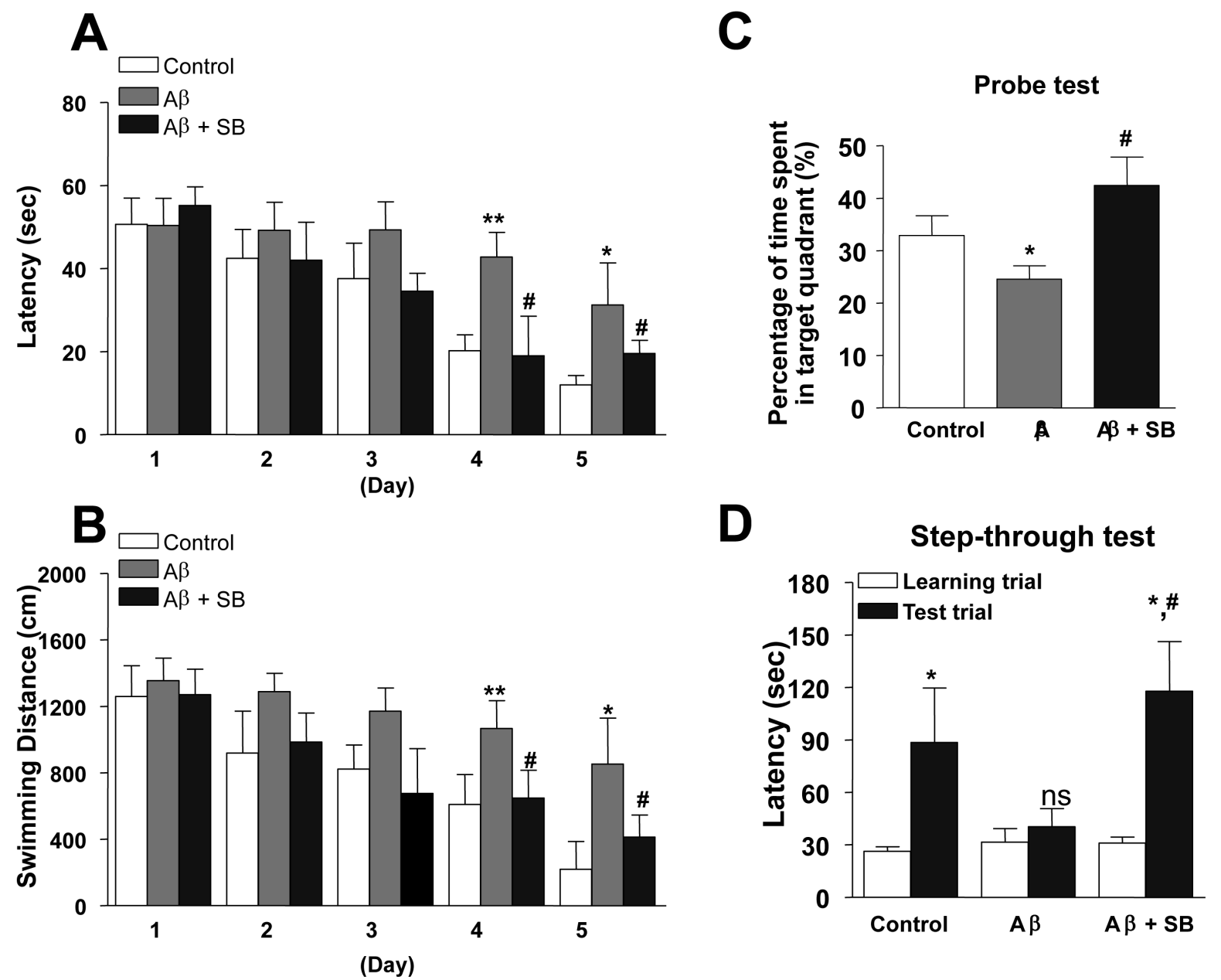

Figure 1: Inhibitory effects of SB271046 on memory impairment in the AD mouse model. A.-C. Training trial was performed three times a day for 5 days. Swimming time A. and swimming distance B. to arrive at platform were automatically recorded. $24 \mathrm{hr}$ after training trials, a probe test was performed. The time spent in the target quadrant and target site crossing within $60 \mathrm{~s}$ was represented $\mathbf{C}$.. Each value is presented as mean \pm S.E.M from 10 mice. D. To perform passive avoidance test, the mice were given electric shock when entered into the dark compartment for training on learning day. After one day, the retention time in illuminated compartment was recorded. Each value is presented as mean \pm S.E.M. from 10 mice. ${ }^{*}$, Significant difference ${ }^{*},{ }^{*} P<0.05$ and $\left.{ }^{* *} P<0.01\right)$. 
AD mouse model, we performed behavioral tests using Morris water maze and passive avoidance tests. Mice were subjected to the Morris water maze test which is a widely known test for learning and memory. We found that $\mathrm{A} \beta_{1-42}$ infused mice learned more slowly than did control mice, as evidenced by slower escape latency during the acquisition training days without any difference in swim speed (Figure 1A, 1B). The learning and memory deficit was rescued after administration of SB271046 (10 mg/ $\mathrm{kg}$, once daily, i.p) (Figure 1A, 1B). Probe test was also confirmed the beneficial effect of SB271046 by calculating the time spent in the target quadrant zone (Figure 1C). We, next, subjected mice to the passive avoidance test that they learned to avoid a dark chamber after exposure to an electrical foot shock, followed by a retention test on the next day. Learning and memory capacities were impaired in $\mathrm{A} \beta_{1-42}$ infused mice, as evidenced by a significant reduction in latency to enter the dark chamber. Administration of SB271046 restored the learning and memory deficit in the passive avoidance test (Figure 1D).

To investigate whether SB271046 influenced amyloidogenesis, the levels of $\mathrm{A} \beta_{1-42}$ was determined with ELISA analysis. Elevated $\mathrm{A} \beta_{1-42}$ was significantly lowered by SB271046 in the AD mouse model (Figure 2A). As assessed by enzymatic cleavage assays to measure $\beta$ and $\gamma$-secretase activity, the activity of $\beta$ and $\gamma$-secretase significantly increased in the brain of AD mouse model (Figure 2B, 2C). The alteration in $\beta$-secretase activity was not changed by the administration of SB271046 (Figure 2B), however, -secretase activity was attenuated by SB271046 in the AD mouse model (Figure 2C). We, next, investigated inflammatory response. Consistent with a previous report [20-21], we found that GFAPpositive cells (astrocytes), Iba1-positive cells (microglia), and iNOS were elevated in the AD mouse model, while SB271046 attenuated the expression of GFAP, Iba1, and iNOS (Figure 2D-2F).
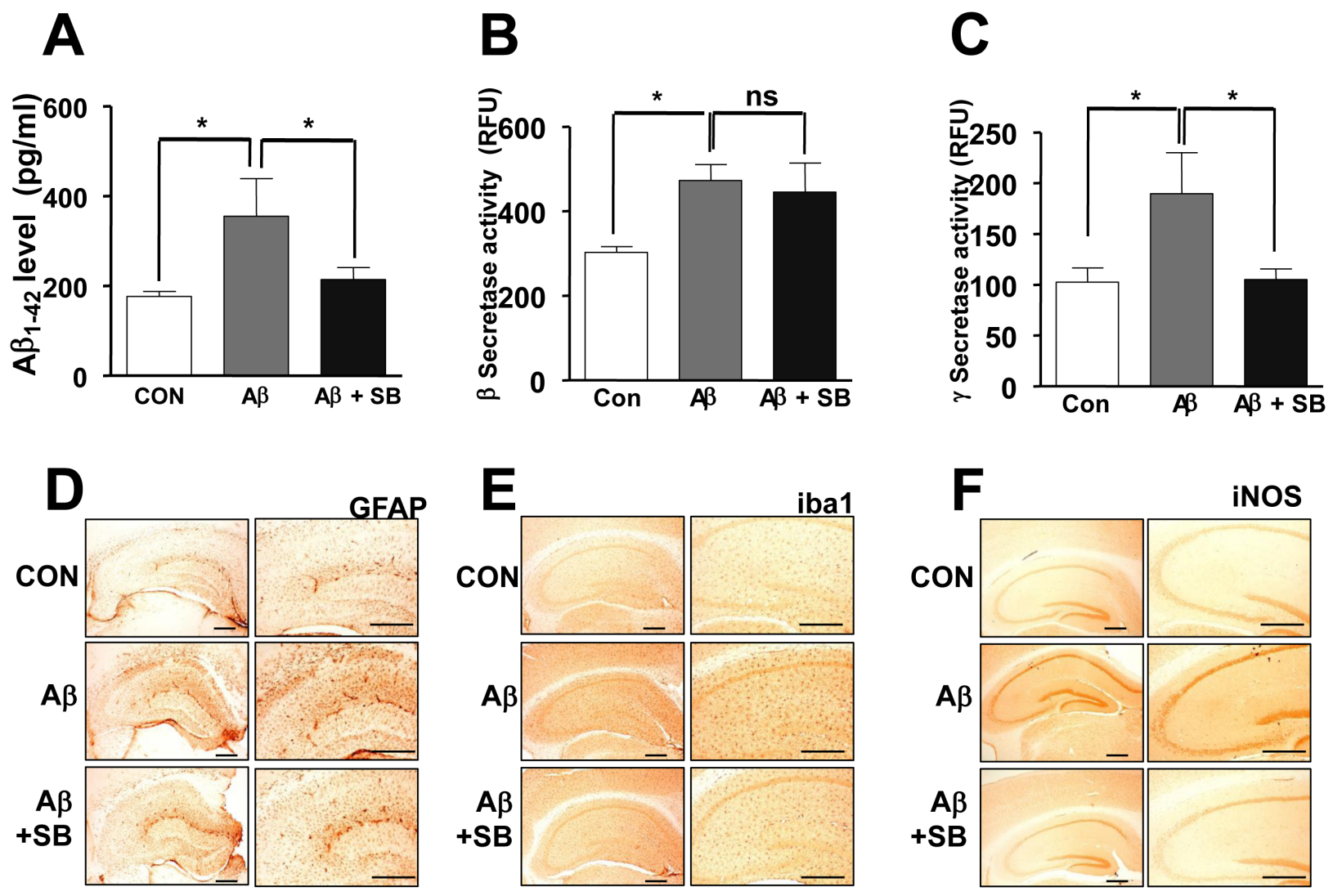

Figure 2: Inhibitory effects of SB271046 on Aß1-42 generation and neuroinflammation in the AD mouse model. A. $\mathrm{A} \beta_{1-42}$ level was measured in mouse brains by ELISA as described in Materials and Methods. Value is mean \pm S.E.M of 8 mice. B., C. The activities of $\beta$-secretase B. and $\gamma$-secretase C. were carried out by using each assay kit as described in Methods. Value is mean \pm S.E.M of 8 mice. D., E. The effect of SB271046 on reactive astrocytes and activated microglia cells was measured by immunohistochemical analysis. The sections of mice brain incubated with anti-glial fibrillary acidic protein (GFAP) D. and anti-ionized calcium binding adaptor molecule 1 (Iba1) E. antibodies, followed by the biotinylated secondary antibody $(n=8)$. The stained tissues were viewed with a microscope $(\times 50$ or 200). F. The sections of mouse brain were incubated with anti-iNOS antibody, and then followed by the biotinylated secondary antibody $(n=8)$. The resulting tissue was viewed with a microscope. ${ }^{*, \#}$ Significant difference $\left({ }^{*}, \#<0.05\right)$. The experiments shown in Figure 2 were repeated in triplicate with similar results. 


\section{5-HT 6 -mediated GABA regulation reverses cognitive impairment in the AD mouse model}

We showed that 5 - $\mathrm{HT}_{6} \mathrm{R}$ was distributed in dorsal raphe nucleus (DRN), cortex (Cx), and hippocampus $(\mathrm{Hp})$ regions $(\mathrm{CA} 1, \mathrm{CA} 3, \mathrm{DG})$ region in the mouse brains (Figure $3 \mathrm{~A}$ ), and it was previously reported that WAY181187 tonically decreased neurotransmitter serotonin level in the brains, and the effect was reversed by SB271046 [22], implying that 5-HT R may play important roles on serotonergic neurons. Therefore, we investigated whether $5-\mathrm{HT}_{6} \mathrm{R}$ is involved in regulation of serotonergic neurons in the AD mouse model. As shown in Figure 3B, serotonin level was lowered by $\mathrm{A} \beta_{1-42}$ infusion, however SB271046 rescued serotonin level in AD mouse model. However, there was no difference on the cell number of TPH2-positive cells (serotonergic neurons) (Figure 3C), suggesting that $5-\mathrm{HT}_{6} \mathrm{R}$ is not a direct modulator on serotonergic neurons to release serotonin. Since it has been reported that 5-HT ${ }_{6} \mathrm{R}$ was colocalized in GABAergic neurons [8], we measured inhibitory neurotransmitter GABA level in AD mouse model. SB271046 significantly decreased GABA level in AD mouse model (Figure $3 \mathrm{D})$, suggesting 5 - $\mathrm{HT}_{6} \mathrm{R}$ regulates serotonergic neurons and serotonin release via GABA. We explored whether the increased serotonin was able to improve memory impairment with same experiment of SB271046 in the $\mathrm{AD}$ mouse model. A selective serotonin reuptake inhibitor (SSRI), Fluoxetine showed significantly better performance on the water maze test in $\mathrm{AD}$ mouse model (Figure 4A, 4B). During the probe test, we calculated the time spent in the target quadrant zone during the 60 second test. The memory deficiency was significantly improved by Fluoxetine (Figure 4C). To further determine whether
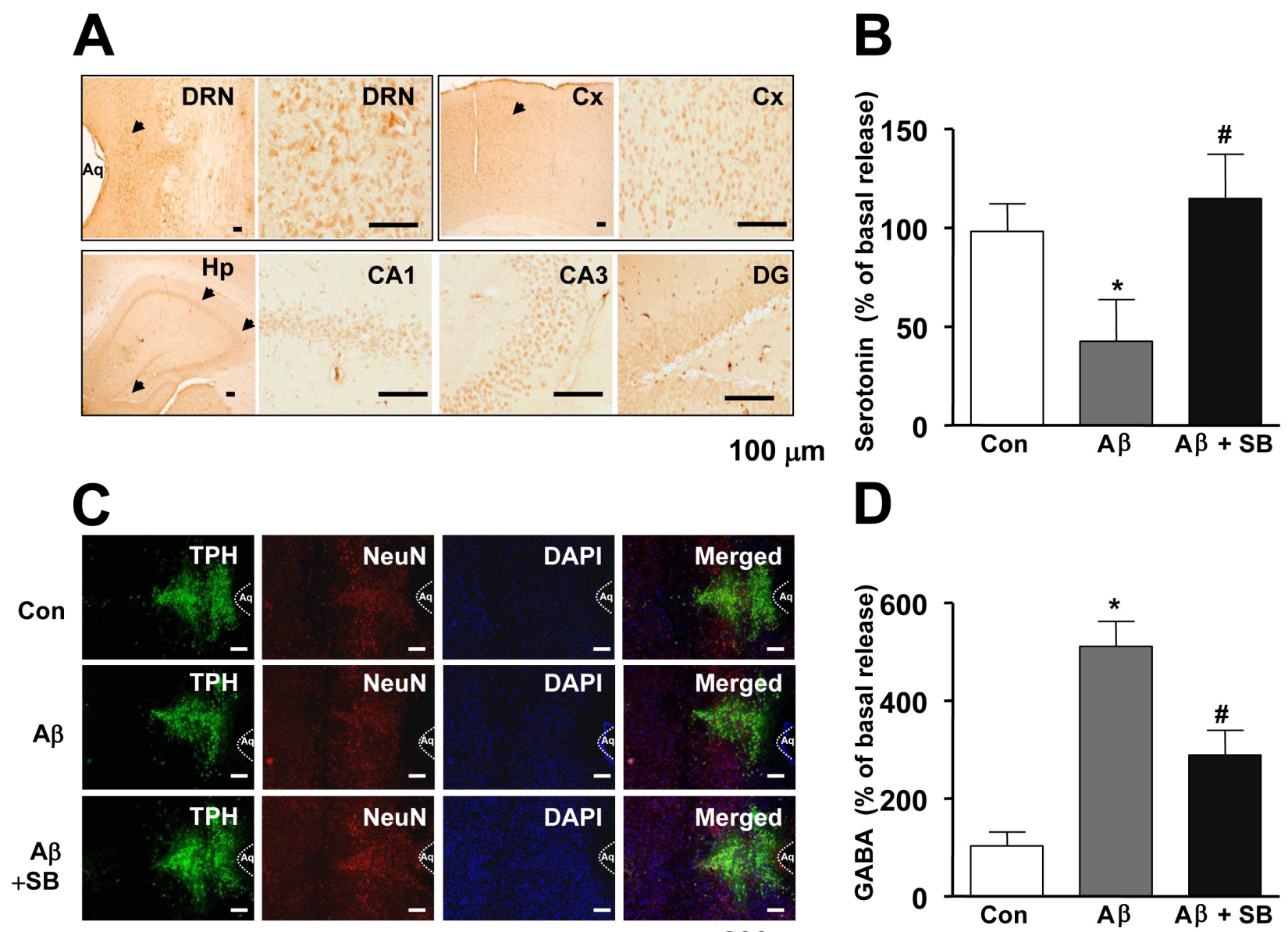

D

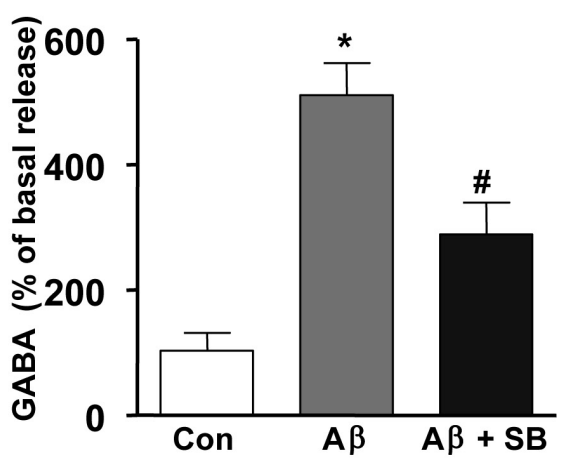

Figure 3: Distribution of 5-HT6R in the mouse brain, and effect of SB271046 on serotonergic neurons in the AD mouse model. A. The DRN, Cx, and $\mathrm{Hp}$ (CA1, CA3, and DG) region of mice brain were analyzed using 5-HT $\mathrm{R}_{6}$ antibodies. The stained tissues were viewed with a microscope $(\times 50$ or 200). B. Serotonin level was measured by ELISA as described in Materials and Methods. Value is mean \pm S.E.M of 8 mice. C. After tissue sections were permeabilized, TPH (green) was immunostained with rabbit anti-TPH antibody followed by Alexa-Fluor 488-conjugated secondary antibodies, and neuronal cells (red) were immunostained with mouse anti-NeuN, followed by Alexa-Fluor 568-conjugated secondary antibodies. And then sections were stained with DAPI (blue). The right panels show the merged images of the first, second, and third panels. D. GABA level was measured by ELISA as described in Materials and Methods. Value is mean \pm S.E.M of 8 mice. ${ }^{* *}$ Significant difference $\left({ }^{*, *} P<0.05\right)$. The experiments shown in Figure 3 were repeated in triplicate with similar results. 
Table 1: Correlations between expression levels of isoforms of 5-HT receptors and APBA2 in the hippocampus of individuals with depression and unaffected controls.

\begin{tabular}{|l|l|l|}
\hline & APBA1 & APBA2 \\
\hline HTR ${ }_{F}$ & $\mathrm{r}=0.1814$ & $\mathrm{r}=-0.0413$ \\
\hline & $\mathrm{n} . \mathrm{s}$ & $\mathrm{n} . \mathrm{s}$ \\
\hline HTR ${ }_{A}$ & $\mathrm{r}=0.3908$ & $\mathrm{r}=0.0785$ \\
\hline & $\mathrm{p}=0.03$ & $\mathrm{n} . \mathrm{s}$ \\
\hline HTR ${ }_{A}$ & $\mathrm{r}=0.6551$ & $\mathrm{r}=0.5306$ \\
\hline & $\mathrm{p}=0.00009$ & $\mathrm{p}=0.003$ \\
\hline HTR & $\mathrm{r}=0.7663$ & $\mathrm{r}=0.6061$ \\
\hline & $\mathrm{p}=0.0000008$ & $\mathrm{p}=0.0004$ \\
\hline HTR $5_{A}$ & $\mathrm{r}=0.6968$ & $\mathrm{r}=0.6175$ \\
\hline & $\mathrm{p}=0.00002$ & $\mathrm{p}=0.0003$ \\
\hline$H T R_{6}$ & $\mathrm{r}=0.7192$ & $\mathrm{r}=0.6022$ \\
\hline & $\mathrm{p}=0.000008$ & $\mathrm{p}=0.0004$ \\
\hline$H T R_{7}$ & $\mathrm{r}=0.7183$ & $\mathrm{r}=0.5303$ \\
\hline & $\mathrm{p}=0.000008$ & $\mathrm{p}=0.003$ \\
\hline
\end{tabular}

Correlation analysis was performed using R. $P$-values less than 0.05 were considered significant. r, Pearson correlation coefficient; $\mathrm{p}, P$-value; n.s, not significant.

A

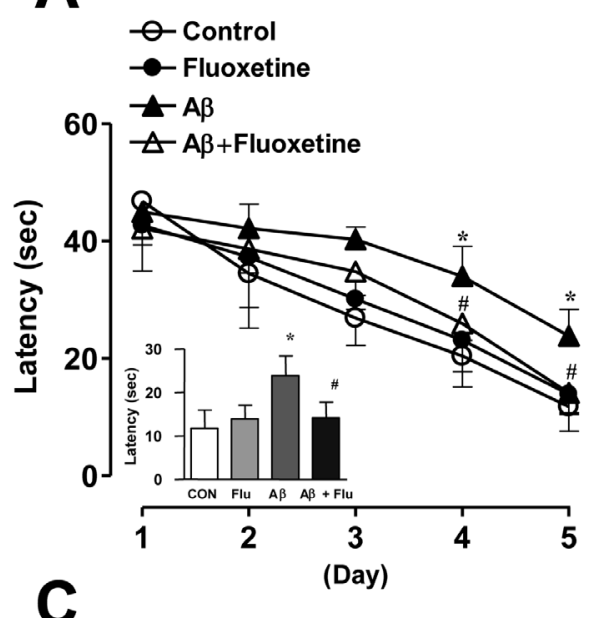

C
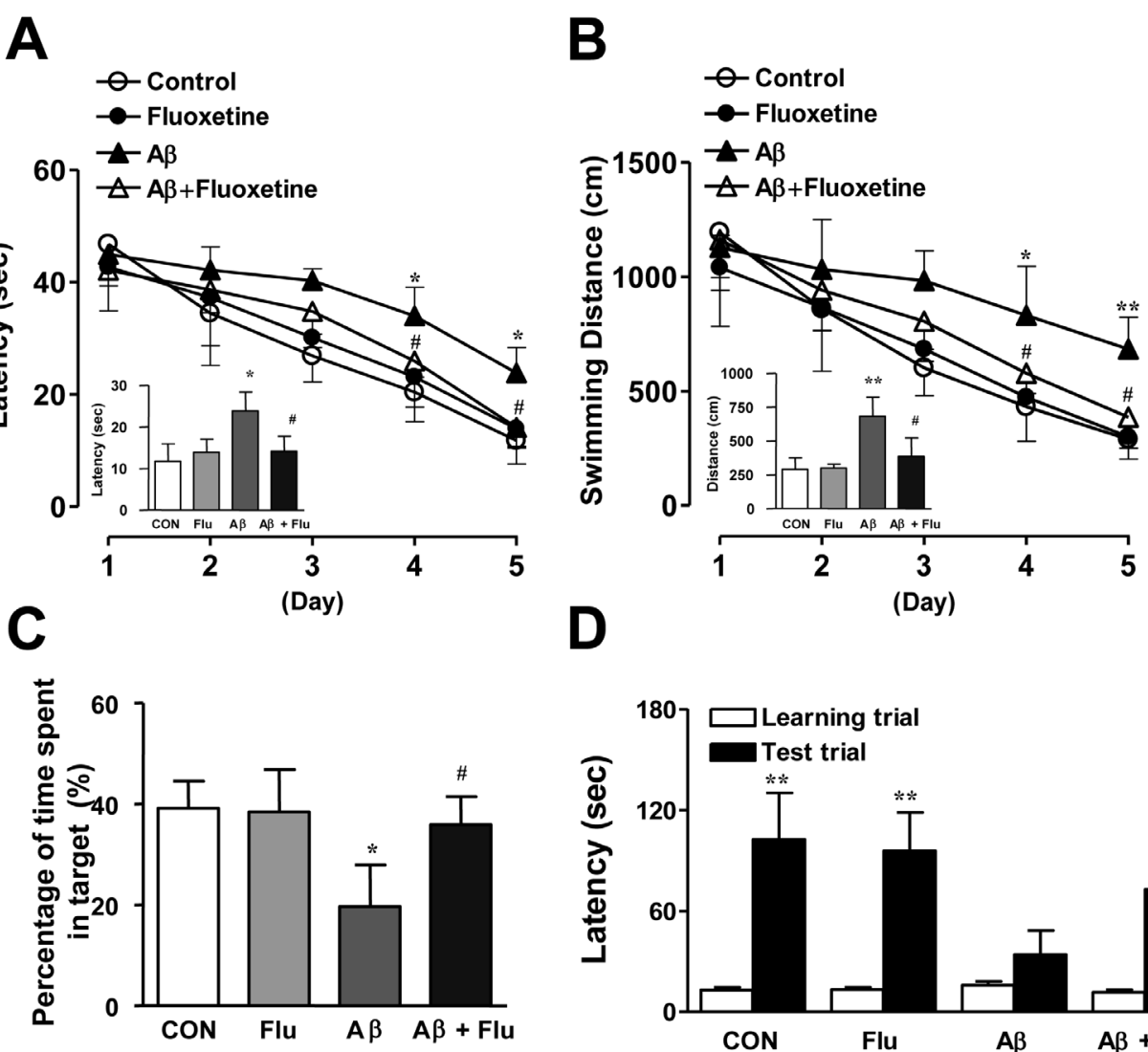

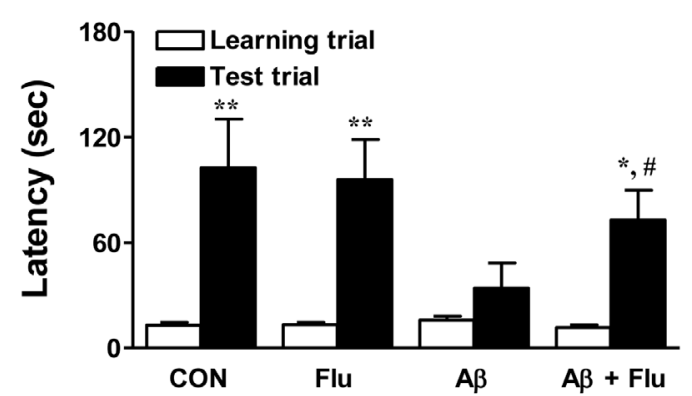

Figure 4: Inhibitory effects of Fluoxetine on memory impairment in Aß1-42-infused mice model. A.-C. Swimming time A. and swimming distance B. to arrive at platform were automatically recorded. $24 \mathrm{hr}$ after training trials, a probe test was performed. The time spent in the target quadrant and target site crossing within $60 \mathrm{~s}$ was represented C.. Each value is presented as mean \pm S.E.M from 10 mice. D. One day after the mice were given electric shock when entered into the dark compartment for training on learning day, the retention time in illuminated compartment was recorded. Each value is presented as mean \pm S.E.M. from 10 mice. ${ }^{*}$, Significant difference $\left({ }^{*}, P<0.05\right.$ and $\left.{ }^{* *} P<0.01\right)$. 
Table 2: Demographic variables of samples used in the SNCID and correlation analyses.

\begin{tabular}{|l|l|l|l|l|}
\hline & Schizophrenia & Bipolar Disorder & Major Depression & $\begin{array}{l}\text { Normal Control } \\
\text { Subjects }\end{array}$ \\
\hline Age (y) & $44.2(25-62)$ & $42.3(25-61)$ & $46.5(30-65)$ & $48.1(29-68)$ \\
\hline Gender & $9 \mathrm{M}, 6 \mathrm{~F}$ & $9 \mathrm{M}, 6 \mathrm{~F}$ & $9 \mathrm{M}, 6 \mathrm{~F}$ & $9 \mathrm{M}, 6 \mathrm{~F}$ \\
\hline Race & $12 \mathrm{C}, 3 \mathrm{~A}$ & $14 \mathrm{C}, 1 \mathrm{AA}$ & $15 \mathrm{C}$ & $14 \mathrm{C}, 1 \mathrm{AA}$ \\
\hline PMI (hrs) & $33.7(12-61)$ & $32.5(13-62)$ & $27.5(7-47)$ & $23.7(8-42)$ \\
\hline $\mathrm{pH}$ & $6.1(5.8-6.6)$ & $6.2(5.8-6.5)$ & $6.2(5.6-6.5)$ & $6.3(5.8-6.6)$ \\
\hline hemisphere & $6 \mathrm{R}, 9 \mathrm{~L}$ & $8 \mathrm{R}, 7 \mathrm{~L}$ & $6 \mathrm{R}, 9 \mathrm{~L}$ & $7 \mathrm{R}, 8 \mathrm{~L}$ \\
\hline
\end{tabular}

M, male; F, female; C, Caucasian; AA, African American; Asian; L, left; R, right.

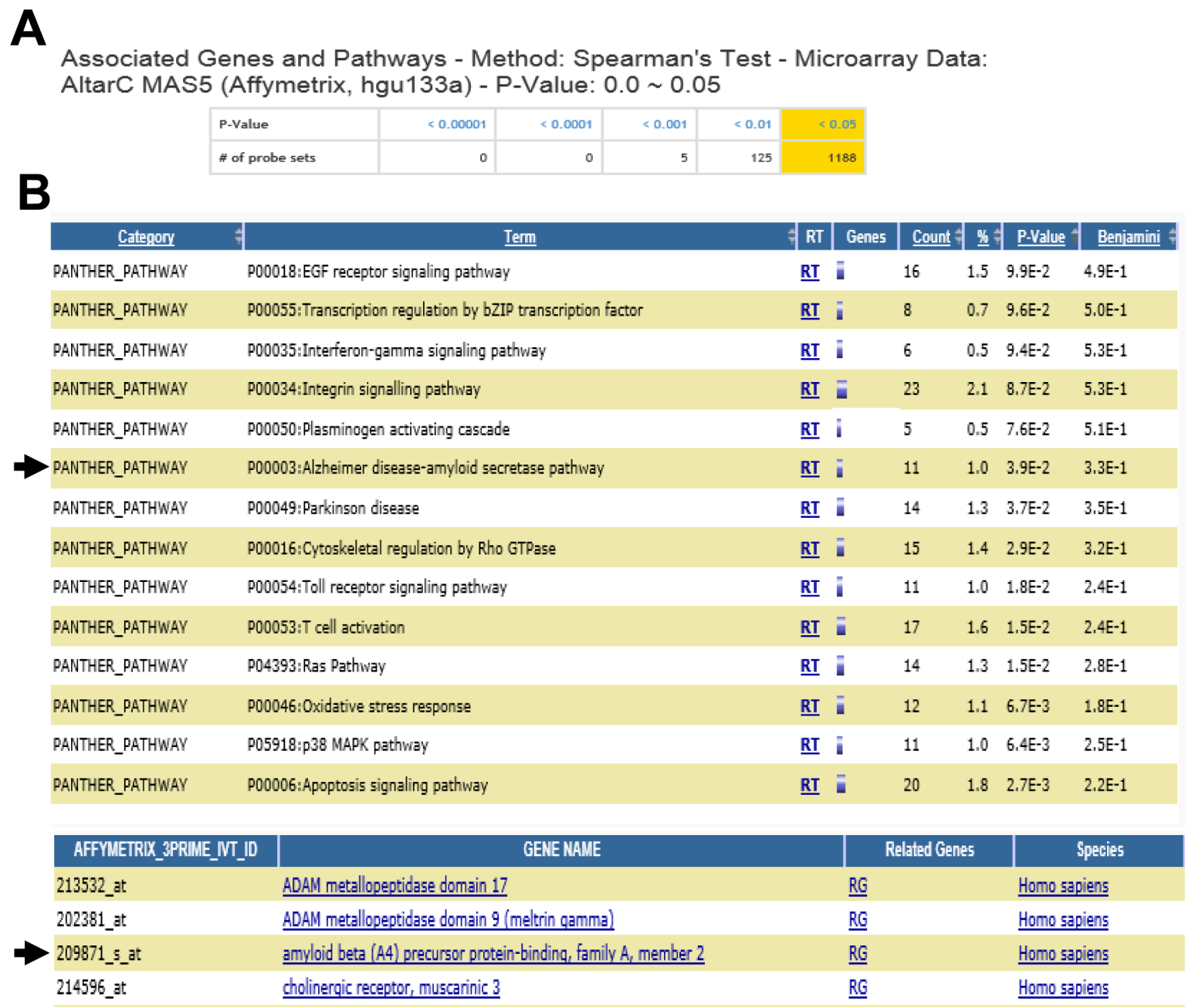

Figure 5: Total number of probe sets and significantly associated biological processes. A. Screen shot captures the number of probe sets by p-values from genome-wide correlation analysis. B. Pathways were significantly enriched in the probe sets which were correlated with the 5-HT levels $(p<0.05)$. The functional annotation was done using an interface in the SNCID that links the SNCID (http:// sncid.stanleyresearch.org) and DAVID (http://david.abcc.ncifcrf.gov/). 
Fluoxetine improved the contextual memory in AD mouse model, we carried out the passive avoidance test using the step-through method. Fluoxetine significantly increased the step-through latency in AD mouse model (Figure 4D).

\section{APBA1/2 are correlated with $5-\mathrm{HT}_{6} \mathrm{R}$ in depression patients and AD mouse model}

We, next, explored genes and pathways which were associated with serotonin levels in the frontal cortex of individuals with major psychiatric diseases and unaffected controls using the SNCID (sncid.stanleyresearch.org/). A total of 1188 probe sets were significantly correlated with serotonin level (Figure 5A) and a pathway related to Alzheimer disease-amyloid secretase was significantly enriched in the correlated genes (Figure 5B). Expression level of APBA2 (amyloid beta (A4) precursor protein- binding, family A, member 2) was significantly correlated with serotonin level. We further explored correlation between expression levels of two ABPA genes such as APBA1 and APBA2 and those of serotonin receptors in the hippocampus of individuals with depression and unaffected controls using RNA sequencing data which were deposited in the SNCID. Expression levels of 7 isoforms of serotonin receptor genes were analyzed, and $5-\mathrm{HT}_{6} \mathrm{R}$ is closely correlated with APBA1/2 compared to other receptors (Table 1 ). To order to validate the correlation between 5 - $\mathrm{HT}_{6} \mathrm{R}$ and APBA1/2, we analyzed mRNA in depression patients, AD patients, and AD mouse model. As shown in Figure 6A, 5- $\mathrm{HT}_{6} \mathrm{R}$ mRNA was significantly correlated with APBA1 and APBA2 in brain tissues of depression patients. In APP mutant mice of AD, it was also found that level of 5- $\mathrm{HT}_{6} \mathrm{R}$ mRNA was reduced in parallel with APBA2 (Figure 6B, 6C).
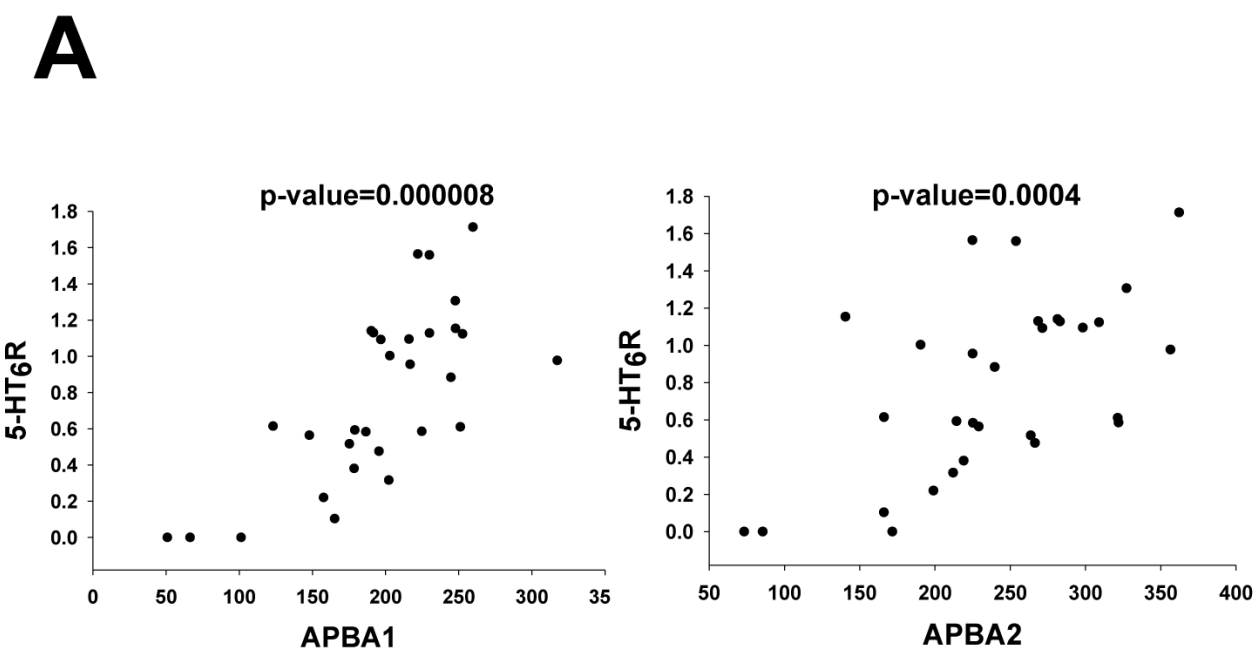

B
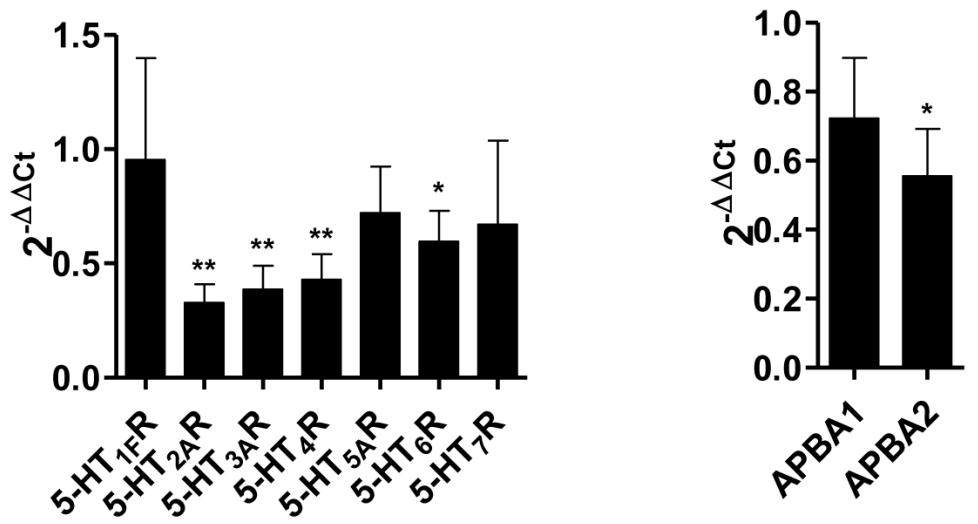

Figure 6: The correlation between APBA1, APBA2 and 5-HT6R in depression and AD. A Correlation between expression levels of 5- $\mathrm{HT}_{6} \mathrm{R}$ and two APBA genes, APBA1 and APBA2. Gene expression levels were measured in the hippocampus of individuals with depression and unaffected controls using RNA-Seq method. (B., C.) The mRNA level of 5-HT, R, 5-HT 2 R, 5-HT $\mathrm{H}_{3}, 5-\mathrm{HT}_{4} \mathrm{R}, 5-\mathrm{HT}{ }_{5} \mathrm{R}$, 5- $\mathrm{HT}_{6} \mathrm{R}$, and 5-HT $\mathrm{R}(\mathbf{B})$, and APBA1/2 (C) was determined by qRT-PCR in APP mutant mice of Alzheimer's disease. 


\section{DISCUSSION}

In the present study, we found that $5-\mathrm{HT}_{6} \mathrm{R}$ improved the symptom of $\mathrm{AD}$. The neurotransmitter serotonin has been known to regulate a variety of neurobehavioral processes, including cognition, memory, and mood [2324]. Serotonergic neurotransmissions were reduced by approximately $40 \%$ in human postmortem material of $\mathrm{AD}$ patients [25-26]. Impaired serotonergic neurotransmission also appeared to be a central dysfunction leading to depression [1]. Disappointingly, none of the approaches have successively resolved correlation between the two diseases, although $\mathrm{AD}$ as a risk factor for depression has been considered and vice versa [4-5]. Actually, it is difficult to search co-effective factors related with depression in $\mathrm{AD}$, since depression is complex mood disorder caused by a variety of reasons such as environmental factors, hereditary factors, and lifestyle [27-28]. Therefore, we planned a strategy to find new co-factors related with $\mathrm{AD}$ via human brain of depression patients within the category of 5- $\mathrm{HT}_{6} \mathrm{R}$ and serotonin. By integrating datasets from neuropathology, microarray, and RNA seq. studies with correlation analysis tools, we identified APBA1/2, known modifiers of APP processing and endocytic trafficking in AD [19]. The molecular mechanisms underlying the suppression of APP amyloidogenic metabolism by APBA1/2 have been addressed. For example, in the brains of APBA1/2 knockout mice, APP metabolism and $A \beta$ generation were suppressed [17, 29-30]. APBA1/2 transgenic mice crossed to APPswe transgenic mice which are used as an $\mathrm{AD}$ mouse model demonstrated reduced $A \beta$ deposition compared [31-32]. Recently, APBA2 was included as several known or novel modifiers in co-expression correlation network analysis of the apolipoprotein E e4 allele (APOE4, a genetic factor in $\mathrm{AD}$ ) and $\mathrm{AD}$ transcriptomic changes [18]. To the best of our knowledge, it has been not reported for the involvement of APBA $1 / 2$ in depression until now. Thus, it is of interest to find the correlation of APBA $1 / 2$ with $5-\mathrm{HT}_{6} \mathrm{R}$ in depression patients. We suggest that APBA1/2 is novel proteins regulated by $5-\mathrm{HT}_{6} \mathrm{R}$ in $\mathrm{AD}$, as well as our data imply the novel function of APBA1/2 via $5-\mathrm{HT}_{6} \mathrm{R}$ in depression.

The dorsal raphe nucleus (DRN) is a brainstem nucleus located in the midbrain and pons, where serotonergic neurons are clustered and project a multitude of brain areas such as cortex, hippocampus, amygdala, basal ganglia, thalamus, and hypothalamus, at which they utilize many transmitters to control various physiological functions, including cognition and emotional states [33-35]. Thus, DRN has been associated with the pathophysiology of a wide spectrum of neuropsychiatric syndromes, such as depression, suicide, and AD. In the present study, it was found that $5-\mathrm{HT}_{6} \mathrm{R}$ was expressed on DRN and its target region, cortex and hippocampus regions (CA1, CA3, and DG), and WAY-181187 tonically decreased serotonin level, which was attenuated by SB271046 [22]. Therefore, we expected that 5- $\mathrm{HT}_{6} \mathrm{R}$ affects serotonergic neurons and regulates serotonin level in the $\mathrm{AD}$ mouse model. However we failed to detect the significant reduction of serotonergic neuron in the $\mathrm{AD}$ mouse model, at which 5- $\mathrm{HT}_{6} \mathrm{R}$ did not affect the number of serotonergic neuron. Our results indicate that $5-\mathrm{HT}_{6} \mathrm{R}$ indirectly regulates serotonin level in the $\mathrm{AD}$ mouse model. Previously, it was reported that $5-\mathrm{HT}_{6} \mathrm{R}$ was colocalized on GABAergic neurons, implying 5- $\mathrm{HT}_{6} \mathrm{R}$ may modify GABAergic neurotransmission in many brain areas via the major inhibitory neurotransmitter GABA [8]. GABAergic afferents synapse with serotonergic neurons and have a significant effect on serotonergic neurons in the DRN [36-37]. $\mathrm{GABA}_{\mathrm{A}}$ and $\mathrm{GABA}_{\mathrm{B}}$ receptor agonists significantly decreased serotonin level [38-39], while $\mathrm{GABA}_{\mathrm{A}}$ receptor antagonists increased serotonin level [40]. In an AD mouse model, GABA release aberrantly increased [41-42], and $\mathrm{GABA}_{A}$ receptor antagonists were shown to improve long term potentiation and memory [43], indicating that the aberrant GABAergic transmission exacerbates cognition in $\mathrm{AD}$ patients. Consistent with this observation, we found that the level of GABA was reduced by $5-\mathrm{HT}_{6} \mathrm{R}$ in the AD mouse model. The observation could be validated in another aspect. Since GABAergic neurons synapse directly with cholinergic neurons [8], the regulation of $5-\mathrm{HT}_{6} \mathrm{R}$ on cholinergic transmission may occur in $\mathrm{AD}$. In the present study, we proved that scopolamine-induced cognitive dysfunction was attenuated by $5-\mathrm{HT}_{6} \mathrm{R}$ (Supplementary Figure 1). The results support our idea for an indirect effect on serotonergic neuron via GABA. Thus, we suggest that 5- $\mathrm{HT}_{6} \mathrm{R}$ controls serotonin level via GABAergic neurons but not serotonergic neurons in the $\mathrm{AD}$ mouse model.

Amyloidogenesis posits that the aberrant metabolism and aggregation of $A \beta$ causes a cascade of neuronal and inflammatory injury, leading to neuronal dysfunction and cell death in $\mathrm{AD}$ [44-46]. In the present study, we demonstrated that $5-\mathrm{HT}_{6} \mathrm{R}$ attenuated the amyloid generation in the $\mathrm{AD}$ mouse model. The effect of 5 - $\mathrm{HT}_{6} \mathrm{R}$ is likely attributable to the activity of $\gamma$-secretase but not $\beta$-secretase activity. We found that SB270146 and Fluoxetine reduced $\gamma$-secretase activity and did not affect $\beta$-secretase activity in the AD mouse model. Several studies support our findings. For instance, it was reported that administration of SSRIs reduced brain $A \beta$ levels in mice [47-48], and also two components of the $\gamma$-secretase complex, presenilin (PS)-1 and nicastrin were significantly reduced in a SSRI, citalopram-treated mice [49]. Furthermore APBA1/2 directly interacted with APP and $\gamma$-secretase and impaired $\gamma$-secretase activity to inhibit $\mathrm{A} \beta$ metabolisms in $\mathrm{AD}[19,50-52]$. Thus, we suggest that the regulation of APBA1/2 via $5-\mathrm{HT}_{6} \mathrm{R}$ improves cognitive dysfunction in the $\mathrm{AD}$ mouse model by inhibiting $\gamma$-secretase activity. Although we firstly found that the network of $5-\mathrm{HT}_{6} \mathrm{R}$-Serotonin-APBA1/2 
occurs in depression patients by analyzing human depression patients, we are further studying to demonstrate the functional network of $5 \mathrm{HT}_{6} \mathrm{R}-$ Serotonin-APBA1/2 in a depression mouse model. In conclusion, we originally investigated the relationship of $5-\mathrm{HT}_{6} \mathrm{R}$-serotoninAPBA1/2 between AD and depression, and we suggest a potential mechanism for the network of $5 \mathrm{HT}_{6} \mathrm{R}$-serotoninAPBA1/2 in the AD mouse model. Our data provide the evidence that the functional network has critical roles in both $\mathrm{AD}$ and depression, as well as provide the concept that the network modulation gives rise to great potential in both prevention and treatment of $\mathrm{AD}$ and depression.

\section{MATERIALS AND METHODS}

\section{Animals}

Male ICR mice (20-25 g) were purchased from Samtako, and were maintained in accordance with the National Institute of Toxicological Research of the Korea Food and Drug Administration guideline for the humane care and use of laboratory animals. All of the experimental procedures in the present study were approved by IACUC of Chungbuk National University (approval number: CBNUA-144-1001-01). Animals were housed in a room that was automatically maintained at $21 \sim 25^{\circ} \mathrm{C}$ and relative humidity $(45 \sim 65 \%)$ with a controlled light-dark cycle. All animals had free access to food (Samyang Foods, Seoul, Korea) and water. Behavioral testing was done during the light cycle of the day (between 14.00-18.00 h). Diethyl ether was used in animal experiments as a euthanasia agent. After appropriate quantity of ether was poured onto cotton wool and allowed to evaporate and fill the chamber, the animals were placed on the ether soaked cotton wool under a mesh so that the animals do not have direct contact with the liquid chemical (ether). After euthanasia, the animal carcasses and the soaked cotton wool were removed and placed inside the chemical fume hood to allow dissipation of the chemical. The extraction system of the fume hood remained switched on for a further period of 30 minutes after the animal carcasses were handled following standard clinical waste procedures.

\section{AD mouse model}

The anesthetized animals were placed in a sterotaxic instrument, and catheters were attached to an osmotic minipump (Alzet 1002, ALZA, Mountain View, CA, USA) and brain infusion kit 1 (Alzet kit 3-5 mm, ALZA, Mountain View, CA, USA) which were implanted according to the following coordinates: mouse (unilaterally): $-1.0 \mathrm{~mm}$ anterior/posterior, $+0.5 \mathrm{~mm}$ medial/lateral and $-2.5 \mathrm{~mm}$ dorsal/ventral. The pump contents were released over a period of 14 days consisting of 300 pmol aggregated $A \beta_{1}$.
${ }_{42}$ (Bachem Chemical, Kashiwa St, Torrance, CA, USA) dissolved in sterile saline $(0.9 \% \mathrm{NaCl})$ for each pump.

\section{Water maze test}

The learning and memory capacity were assessed using two separate tests (water maze and passive avoidance tests). The water maze test is a widely accepted method for testing memory. The examination was performed using the SMART-CS (Panlab, Barcelona, Spain) program and equipment. A circular plastic pool (height $35 \mathrm{~cm}$, diameter $100 \mathrm{~cm}$ ) was filled with water (containing milk) kept at 22$25^{\circ} \mathrm{C}$. An escape platform (height $14.5 \mathrm{~cm}$, diameter 4.5 $\mathrm{cm}$ ) was positioned submerged $0.5-1 \mathrm{~cm}$ below the surface of the water. The test was performed three times per day for 7 days. Each trial lasted for $60 \mathrm{~s}$ or ended as soon as the mouse reached the submerged platform and was allowed to remain on the platform for $2 \mathrm{~s}$. The mice were allowed to swim until they sought the escape platform. Escape latency, escape distance, swimming speed, and swimming pattern of each mouse were monitored by a camera above the center of the pool connected to a SMART-LD program (Panlab, Barcelona, Spain). A quiet environment, consistent lighting, constant water temperature, and fixed spatial frame were maintained throughout the period of the experiment.

\section{Probe test}

A probe test to assess memory consolidation was performed two days after the 7 days acquisition tests. In this test, the platform was removed from the tank, and the mice were allowed to swim freely. For these tests, the spent time on the target quadrant within $60 \mathrm{~s}$ were recorded. The time spent in the target quadrant was taken to indicate the degree of memory consolidation that had taken place after learning. The swimming pattern of each mouse was monitored by a camera above the center of the pool connected to a SMART-LD program as described above.

\section{Passive avoidance performance test}

The passive avoidance test is also widely accepted as a simple and rapid method for testing memory. The passive avoidance response was determined using a "stepthrough" apparatus (Med Associates, Georgia, VT, USA) that consists of an illuminated and a dark compartment (each $20.3 \times 15.9 \times 21.3 \mathrm{~cm})$ adjoining each other through a small gate with a grid floor of $3.175 \mathrm{~mm}$ stainless steel rods set $8 \mathrm{~mm}$ apart. One day after the probe test, the training trial was performed. The mouse was placed in the illuminated compartment facing away from the dark compartment. When the mouse moved completely into the 
dark compartment, it received an electric shock $(1 \mathrm{~mA}, 3 \mathrm{~s}$ duration). Then the mouse was returned to its home cage. One day later, the mouse was placed in the illuminated compartment and the latency period to enter the dark compartment, defined as "retention," was measured. The time when the mouse entered the dark compartment was recorded and described as step-through latency. The retention trials were set at a limit of $180 \mathrm{~s}$ as cut off time.

\section{Brain tissue collection and preservation}

After behavioral tests, animals were perfused with PBS under inhaled diethyl ether anesthetization. The brains were immediately removed from skull, and the cortex and hippocampus were dissected on ice. All the brain tissues were immediately stored at $-80{ }^{\circ} \mathrm{C}$, until biochemical assays were conducted.

\section{Western blot analysis}

Cells and each area of the brain tissue were homogenized and lysed for $30 \mathrm{~min}$ incubation on ice. The lysates were centrifuged at $14,000 \mathrm{rpm}$ for 15 min. An equal amount of total protein $(20 \mu \mathrm{g})$ isolated from brain tissues was resolved on an sodium dodecyl sulfate (SDS) 10 or $12 \%$ polyacrylamide gel and then transferred to a nitrocellulose membrane (Hybond ECL; Amersham Pharmacia Biotech, Piscataway, NJ, USA). Blots were blocked for $1 \mathrm{hr}$ at room temperature with $5 \%(\mathrm{w} / \mathrm{v})$ non-fat dried milk in Tris-buffered saline Tween-20 [TBST: $10 \mathrm{mM}$ Tris $(\mathrm{pH} 8.0)$ and a $150 \mathrm{mM}$ $\mathrm{NaCl}$ solution containing $0.05 \%$ Tween-20]. After a short wash in TBST, membranes were incubated at room temperature with specific. The blot was then incubated with the corresponding conjugated anti-mouse or antirabbit antibodies (1:2000, Santa Cruz Biotechnology). Immunoreactive proteins were detected with the enhanced chemiluminescence (ECL) western blotting detection system.

\section{Immunohistochemistry and Immunofluorescence}

After being anesthetized with diethyl ether, subgroups of mice, were perfused intracardially with $50 \mathrm{ml}$ saline. The brains were taken out from the skull and postfixed in $4 \%$ paraformaldehyde for $24 \mathrm{~h}$ at $4{ }^{\circ} \mathrm{C}$. The brains were transferred to $30 \%$ sucrose solutions. Subsequently, brains were cut into $18 \mu \mathrm{m}$ sections using a cryostat microtome (Leica CM1850; Leica Microsystems, Seoul, South Korea). After multiple washings in PBS, endogenous peroxidase activity was quenched by $1 \%$ hydrogen peroxide in methanol for $30 \mathrm{~min}$ and then cleared in PBS for $5 \mathrm{~min}$. The sections were blocked for $30 \mathrm{~min}$ with $3 \%$ normal horse/goat serum diluted in PBS. These sections were incubated for overnight with appropriate antibodies. After washing in PBS, the sections were incubated in biotinylated goat anti-mouse/ rabbit IgG antibody (1:1000 dilution, Vector Laboratories, Burlingame, CA, USA) for $1 \mathrm{hr}$ at room temperature. The sections were subsequently washed and incubated with avidin-conjugated peroxidase complex (ABC kit, 1:200 dilution, Vector Laboratories, Burlingame, CA, USA) for 30 min followed by PBS washing. The peroxidase reaction was performed in PBS using 3, 3'-diaminobenzidine tetrahydrochloride (DAB, $0.02 \%$ ) as the chromogen. Finally, the sections were rinsed, mounted on polyglycine-coated slides, dehydrated, and cover-slipped for light microscopy and photography. Finally, sections were dehydrated in ethanol, cleared in xylene, and mounted with Permount (Fisher Scientific), and evaluated on a light microscopy (Olympus, Tokyo, Japan). For Immunofluorescence, sections were incubated with an anti-rabbit secondary antibody labeled with Alexa-Fluor 488 (1:400 dilution, Invitrogen) or anti-mouse secondary antibody labeled with Alexa-Fluor 568 (1:400 dilution, Invitrogen) for $2 \mathrm{~h}$ at room temperature. Final images were viewed on a confocal LSM 510 Laser Scanning microscope (Zeiss, Gottingen, Germany).

\section{Measurement of A $\beta 1-42$}

Lysates of brain tissue were obtained through protein extraction buffer containing protease inhibitor. $A \beta_{1}$. ${ }_{42}$ level was determined using each specific enzyme-linked immunosorbent assay (ELISA) Kit (Immuno-Biological Laboratories Co., Ltd., Takasaki-Shi, Gunma, Japan). In brief, $100 \mu \mathrm{l}$ of sample was added into the precoated plate and was incubated for overnight at $4{ }^{\circ} \mathrm{C}$. After washing each well of the precoated plate with washing buffer, 100 $\mu \mathrm{l}$ of labeled antibody solution was added and the mixture was incubated for $1 \mathrm{hr}$ at $4{ }^{\circ} \mathrm{C}$ in the dark. After washing, chromogen was added and the mixture was incubated for $30 \mathrm{~min}$ at room temperature in the dark. Finally, the resulting color was assayed at $450 \mathrm{~nm}$ using a microplate absorbance reader (SunriseTM, TECAN, Switzerland) after adding stop solution.

\section{Measurement of $\beta$ - and $\gamma$-secretase activities}

$\beta$-Secretase activity in all mice brains was determined using a commercially available $\beta$-secretase activity kit (R\&D Systems, Minneapolis, MN, USA) and a BACE1 fluorescence resonance energy transfer assay kit (Panvera, Madison, WI, USA). Fluorescence was read at excitation and emission wavelengths of 355 and $510 \mathrm{~nm}$, respectively, using a Fluostar Galaxy fluorimeter (BMG Lab Technologies, Offenburg, Germany) with Felix software (BMG Lab Technologies, Offenburg, Germany). $\beta$-Secretase activity is proportional to the fluorimetric 
reaction and is expressed as nanomoles per milligram protein per minute. $\gamma$-secretase activity was performed in ex vitro using CHAPSO-solubilized membrane fractions. Enzyme activity levels were quantified based on the description by Farmery et al [53].

\section{Correlation analysis using the SNCID}

Correlation analyses between 5-HT levels and microarray genome-wide expression data in the frontal cortex of individuals with major psychiatric diseases and unaffected controls were conducted using the SNCID (sncid.stanleyresearch.org/) as previously described (Kim and Webster, 2010b). The SNCID is an archival and mining database which includes numerous neuropathology data, microarray data and RNA-seq data from the brain tissues from subjects in the Stanley Neuropathology Consortium. The Stanley Neuropathology Consortium contains 15 well-matched cases in each of four groups: schizophrenia, bipolar disorder, major depression, and unaffected controls. The diagnostic groups are matched for descriptive variables such as age, gender, race, postmortem interval (PMI), mRNA quality, brain $\mathrm{pH}$, and hemisphere. Demographic variables are listed in Table 2. DAVID (http://david.abcc.ncifcrf.gov/home.jsp) was used to identify the pathways that were significantly overrepresented by the correlated genes. P-values less than 0.05 were considered significant.

\section{Correlation analysis between 5-HT receptor genes and two APBA genes, APBA1 and APBA2 in the hippocampus using RNA-seq data}

The raw RNA sequencing data (FASTAQ files, S1_Table) from the hippocampus of the Stanley Neuropathology Consortium are also available from the SNCID. The RNA-seq data from 15 depression cases and 15 unaffected controls were downloaded for use in this study. We map and quantify the RNA-seq data using the same methods as described in our previous study. In brief, all reads were mapped to the $\mathrm{H}$. sapiens reference genome using TopHat v2.0.0 with the UCSC refFlat gene model annotation file (build hg18) on the -G parameter. We used the expected mean inner distance between mate paired-ends as -r parameter. TopHat calls Bowtie v0.12.7 to perform the alignment with no more than 2 mismatches. The quantification of gene expression was accomplished by HTseq v0.5.3p9 and edger package (http://www. bioconductor.org/packages/2.11/bioc/html/edgeR.html). All mapped read counts of the genes were counted by htseq-count (subprogram of HTseq) with the UCSC refFlat gene model annotation file, no strand specific option, and intersection-nonempty option. We performed Pearson correlation analysis between expression levels of 5-HT receptor genes and the two APBA genes using $\mathrm{R}$.

\section{Statistical analysis}

The data were analyzed using the GraphPad Prism version 4 program (GraphPad Software, Inc., San Diego, CA). Data are presented as mean \pm S.E.M. Satistical significance was performed on the data using one-way analysis of variance (ANOVA) or unpaired Student's $t$ test. A value of $P<0.05$ was considered to be statistically significant.

\section{ACKNOWLEDGMENTS}

This work was supported by the National Research Foundation of Korea (NRF) grant funded by the Korea Government (MSIP) (No. MRC, 2008-0062275 and No. 2012R1A5A2051384), and the POSCO TJ Park Foundation.

\section{CONFLICTS OF INTEREST}

The authors declare no competing financial interests.

\section{REFERENCES}

1. Meltzer CC, Smith G, DeKosky ST, Pollock BG, Mathis CA, Moore RY, Kupfer DJ and Reynolds CF, 3rd. Serotonin in aging, late-life depression, and Alzheimer's disease: the emerging role of functional imaging. Neuropsychopharmacology. 1998; 18:407-430.

2. Parmelee PA, Katz IR and Lawton MP. Depression among institutionalized aged: assessment and prevalence estimation. J Gerontol. 1989; 44:M22-29.

3. Green RC, Cupples LA, Kurz A, Auerbach S, Go R, Sadovnick D, Duara R, Kukull WA, Chui H, Edeki T, Griffith PA, Friedland RP, Bachman D and Farrer L. Depression as a risk factor for Alzheimer disease: the MIRAGE Study. Arch Neurol. 2003; 60:753-759.

4. Ownby RL, Crocco E, Acevedo A, John V and Loewenstein D. Depression and risk for Alzheimer disease: systematic review, meta-analysis, and metaregression analysis. Arch Gen Psychiatry. 2006; 63:530-538.

5. Rapp MA, Schnaider-Beeri M, Grossman HT, Sano M, Perl DP, Purohit DP, Gorman JM and Haroutunian V. Increased hippocampal plaques and tangles in patients with Alzheimer disease with a lifetime history of major depression. Arch Gen Psychiatry. 2006; 63:161-167.

6. Rapp MA, Schnaider-Beeri M, Purohit DP, Perl DP, Haroutunian V and Sano M. Increased neurofibrillary tangles in patients with Alzheimer disease with comorbid depression. Am J Geriatr Psychiatry. 2008; 16:168-174.

7. Kohen R, Metcalf MA, Khan N, Druck T, Huebner K, Lachowicz JE, Meltzer HY, Sibley DR, Roth BL and Hamblin MW. Cloning, characterization, and chromosomal localization of a human 5-HT6 serotonin receptor. J 
Neurochem. 1996; 66:47-56.

8. Woolley ML, Marsden CA and Fone KC. 5-ht6 receptors. Curr Drug Targets CNS Neurol Disord. 2004; 3:59-79.

9. Roth BL, Craigo SC, Choudhary MS, Uluer A, Monsma FJ, Jr., Shen Y, Meltzer HY and Sibley DR. Binding of typical and atypical antipsychotic agents to 5-hydroxytryptamine-6 and 5-hydroxytryptamine-7 receptors. J Pharmacol Exp Ther. 1994; 268:1403-1410.

10. Yun HM, Baik JH, Kang I, Jin C and Rhim H. Physical interaction of Jab1 with human serotonin 6 G-proteincoupled receptor and their possible roles in cell survival. J Biol Chem. 2010; 285:10016-10029.

11. Yun HM, Kim S, Kim HJ, Kostenis E, Kim JI, Seong JY, Baik JH and Rhim H. The novel cellular mechanism of human 5-HT6 receptor through an interaction with Fyn. J Biol Chem. 2007; 282:5496-5505.

12. Garcia-Alloza M, Hirst WD, Chen CP, Lasheras B, Francis PT and Ramirez MJ. Differential involvement of $5-\mathrm{HT}(1 \mathrm{~B} / 1 \mathrm{D})$ and 5 -HT6 receptors in cognitive and non-cognitive symptoms in Alzheimer's disease. Neuropsychopharmacology. 2004; 29:410-416.

13. Upton N, Chuang TT, Hunter AJ and Virley DJ. 5-HT6 receptor antagonists as novel cognitive enhancing agents for Alzheimer's disease. Neurotherapeutics. 2008; 5:458469.

14. Foley AG, Murphy KJ, Hirst WD, Gallagher HC, Hagan JJ, Upton N, Walsh FS and Regan CM. The 5-HT(6) receptor antagonist SB-271046 reverses scopolamine-disrupted consolidation of a passive avoidance task and ameliorates spatial task deficits in aged rats. Neuropsychopharmacology. 2004; 29:93-100.

15. Wesolowska A and Nikiforuk A. Effects of the brainpenetrant and selective 5-HT6 receptor antagonist SB399885 in animal models of anxiety and depression. Neuropharmacology. 2007; 52:1274-1283.

16. Wesolowska A, Nikiforuk A and Stachowicz K. Anxiolyticlike and antidepressant-like effects produced by the selective 5-HT6 receptor antagonist SB-258585 after intrahippocampal administration to rats. Behav Pharmacol. 2007; 18:439-446.

17. Saito Y, Sano Y, Vassar R, Gandy S, Nakaya T, Yamamoto $\mathrm{T}$ and Suzuki T. X11 proteins regulate the translocation of amyloid beta-protein precursor (APP) into detergentresistant membrane and suppress the amyloidogenic cleavage of APP by beta-site-cleaving enzyme in brain. J Biol Chem. 2008; 283:35763-35771.

18. Rhinn H, Fujita R, Qiang L, Cheng R, Lee JH and Abeliovich A. Integrative genomics identifies APOE epsilon4 effectors in Alzheimer's disease. Nature. 2013; 500:45-50.

19. Miller CC, McLoughlin DM, Lau KF, Tennant ME and Rogelj B. The X11 proteins, Abeta production and Alzheimer's disease. Trends Neurosci. 2006; 29:280-285.

20. Yun HM, Kim HS, Park KR, Shin JM, Kang AR, il Lee
K, Song S, Kim YB, Han SB, Chung HM and Hong JT. Placenta-derived mesenchymal stem cells improve memory dysfunction in an Abeta1-42-infused mouse model of Alzheimer's disease. Cell Death Dis. 2013; 4:e958.

21. Yun HM, Jin P, Han JY, Lee MS, Han SB, Oh KW, Hong SH, Jung EY and Hong JT. Acceleration of the development of Alzheimer's disease in amyloid betainfused peroxiredoxin 6 overexpression transgenic mice. Mol Neurobiol. 2013; 48:941-951.

22. Schechter LE, Lin Q, Smith DL, Zhang G, Shan Q, Platt B, Brandt MR, Dawson LA, Cole D, Bernotas R, Robichaud A, Rosenzweig-Lipson $\mathrm{S}$ and Beyer CE. Neuropharmacological profile of novel and selective 5-HT6 receptor agonists: WAY-181187 and WAY-208466. Neuropsychopharmacology. 2008; 33:1323-1335.

23. Buhot MC. Serotonin receptors in cognitive behaviors. Curr Opin Neurobiol. 1997; 7:243-254.

24. Svenningsson P, Tzavara ET, Qi H, Carruthers R, Witkin JM, Nomikos GG and Greengard P. Biochemical and behavioral evidence for antidepressant-like effects of 5-HT6 receptor stimulation. J Neurosci. 2007; 27:4201-4209.

25. Chen CP, Eastwood SL, Hope T, McDonald B, Francis PT and Esiri MM. Immunocytochemical study of the dorsal and median raphe nuclei in patients with Alzheimer's disease prospectively assessed for behavioural changes. Neuropathol Appl Neurobiol. 2000; 26:347-355.

26. Hendricksen $M$, Thomas AJ, Ferrier IN, Ince P and O'Brien JT. Neuropathological study of the dorsal raphe nuclei in late-life depression and Alzheimer's disease with and without depression. Am J Psychiatry. 2004; 161:1096-1102.

27. Mill J and Petronis A. Molecular studies of major depressive disorder: the epigenetic perspective. Mol Psychiatry. 2007; 12:799-814.

28. Dominguez-Lopez S, Howell $\mathrm{R}$ and Gobbi G. Characterization of serotonin neurotransmission in knockout mice: implications for major depression. Rev Neurosci. 2012; 23:429-443.

29. Sano Y, Syuzo-Takabatake A, Nakaya T, Saito Y, Tomita $\mathrm{S}$, Itohara $\mathrm{S}$ and Suzuki T. Enhanced amyloidogenic metabolism of the amyloid beta-protein precursor in the X11L-deficient mouse brain. J Biol Chem. 2006; 281:37853-37860.

30. Kondo M, Shiono M, Itoh G, Takei N, Matsushima T, Maeda M, Taru H, Hata S, Yamamoto T, Saito Y and Suzuki T. Increased amyloidogenic processing of transgenic human APP in X11-like deficient mouse brain. Mol Neurodegener. 2010; 5:35.

31. Lee JH, Lau KF, Perkinton MS, Standen CL, Rogelj B, Falinska A, McLoughlin DM and Miller CC. The neuronal adaptor protein X11beta reduces amyloid beta-protein levels and amyloid plaque formation in the brains of transgenic mice. J Biol Chem. 2004; 279:49099-49104.

32. Lee JH, Lau KF, Perkinton MS, Standen CL, Shemilt SJ, Mercken L, Cooper JD, McLoughlin DM and Miller CC. 
The neuronal adaptor protein X11alpha reduces Abeta levels in the brains of Alzheimer's APPswe Tg2576 transgenic mice. J Biol Chem. 2003; 278:47025-47029.

33. Fuxe K, Dahlstrom A, Hoistad M, Marcellino D, Jansson A, Rivera A, Diaz-Cabiale Z, Jacobsen K, Tinner-Staines B, Hagman B, Leo G, Staines W, Guidolin D, Kehr J, Genedani S, Belluardo N, et al. From the Golgi-Cajal mapping to the transmitter-based characterization of the neuronal networks leading to two modes of brain communication: wiring and volume transmission. Brain Res Rev. 2007; 55:17-54.

34. Michelsen KA, Prickaerts J and Steinbusch HW. The dorsal raphe nucleus and serotonin: implications for neuroplasticity linked to major depression and Alzheimer's disease. Prog Brain Res. 2008; 172:233-264.

35. Hornung JP. The human raphe nuclei and the serotonergic system. J Chem Neuroanat. 2003; 26:331-343.

36. Wang QP, Ochiai H and Nakai Y. GABAergic innervation of serotonergic neurons in the dorsal raphe nucleus of the rat studied by electron microscopy double immunostaining. Brain Res Bull. 1992; 29:943-948.

37. Gervasoni D, Peyron C, Rampon C, Barbagli B, Chouvet G, Urbain N, Fort P and Luppi PH. Role and origin of the GABAergic innervation of dorsal raphe serotonergic neurons. J Neurosci. 2000; 20:4217-4225.

38. Tao R, Ma Z and Auerbach SB. Alteration in regulation of serotonin release in rat dorsal raphe nucleus after prolonged exposure to morphine. J Pharmacol Exp Ther. 1998; 286:481-488.

39. Innis RB and Aghajanian GK. Pertussis toxin blocks 5-HT1A and GABAB receptor-mediated inhibition of serotonergic neurons. Eur J Pharmacol. 1987; 143:195-204.

40. Tao R and Auerbach SB. GABAergic and glutamatergic afferents in the dorsal raphe nucleus mediate morphineinduced increases in serotonin efflux in the rat central nervous system. J Pharmacol Exp Ther. 2002; 303:704-710.

41. Zhou ZN, Sharma VP, Beaty BT, Roh-Johnson M, Peterson EA, Van Rooijen N, Kenny PA, Wiley HS, Condeelis JS and Segall JE. Autocrine HBEGF expression promotes breast cancer intravasation, metastasis and macrophageindependent invasion in vivo. Oncogene. 2014; 33:37843793 .

42. Samakashvili S, Ibanez C, Simo C, Gil-Bea FJ, Winblad B, Cedazo-Minguez A and Cifuentes A. Analysis of chiral amino acids in cerebrospinal fluid samples linked to different stages of Alzheimer disease. Electrophoresis. 2011; 32:2757-2764.

43. Yoshiike Y, Kimura T, Yamashita S, Furudate H, Mizoroki T, Murayama M and Takashima A. GABA(A) receptormediated acceleration of aging-associated memory decline in APP/PS1 mice and its pharmacological treatment by picrotoxin. PLoS One. 2008; 3:e3029.

44. Selkoe DJ. The molecular pathology of Alzheimer's disease. Neuron. 1991; 6:487-498.
45. Hardy J. Alzheimer's disease: the amyloid cascade hypothesis: an update and reappraisal. J Alzheimers Dis. 2006; 9:151-153.

46. Hardy JA and Higgins GA. Alzheimer's disease: the amyloid cascade hypothesis. Science. 1992; 256:184-185.

47. Tucker S, Ahl M, Cho HH, Bandyopadhyay S, Cuny GD, Bush AI, Goldstein LE, Westaway D, Huang X and Rogers JT. RNA therapeutics directed to the non coding regions of APP mRNA, in vivo anti-amyloid efficacy of paroxetine, erythromycin, and N-acetyl cysteine. Curr Alzheimer Res. 2006; 3:221-227.

48. Nelson RL, Guo Z, Halagappa VM, Pearson M, Gray AJ, Matsuoka Y, Brown M, Martin B, Iyun T, Maudsley S, Clark RF and Mattson MP. Prophylactic treatment with paroxetine ameliorates behavioral deficits and retards the development of amyloid and tau pathologies in 3xTgAD mice. Exp Neurol. 2007; 205:166-176.

49. Cirrito JR, Disabato BM, Restivo JL, Verges DK, Goebel WD, Sathyan A, Hayreh D, D’Angelo G, Benzinger T, Yoon H, Kim J, Morris JC, Mintun MA and Sheline YI. Serotonin signaling is associated with lower amyloid-beta levels and plaques in transgenic mice and humans. Proc Natl Acad Sci U S A. 2011; 108:14968-14973.

50. Lau KF, McLoughlin DM, Standen CL, Irving NG and Miller CC. Fe65 and X11beta co-localize with and compete for binding to the amyloid precursor protein. Neuroreport. 2000; 11:3607-3610.

51. King GD, Cherian K and Turner RS. X11alpha impairs gamma- but not beta-cleavage of amyloid precursor protein. J Neurochem. 2004; 88:971-982.

52. Lau KF, McLoughlin DM, Standen C and Miller CC. X11 alpha and $\mathrm{x} 11$ beta interact with presenilin-1 via their PDZ domains. Mol Cell Neurosci. 2000; 16:557-565.

53. Farmery MR, Tjernberg LO, Pursglove SE, Bergman A, Winblad B and Naslund J. Partial purification and characterization of gamma-secretase from post-mortem human brain. J Biol Chem. 2003; 278:24277-24284. 